\title{
ANALISIS FAKTOR PENYEBAB SiLPA DAN SILPA PADA BADAN PENGELOLA KEUANGAN DAN ASET DAERAH KABUPATEN MUSI BANYUASIN
}

\author{
Ahmad Irfansyah \\ Sekolah Tinggi Ilmu Ekonomi Rahmaniyah \\ Email : irfansyahahmad2@gmail.com
}

\begin{abstract}
This study aims to determine the factors that cause the remainder of the budget calculation (SiLPA) and the remainder over budget financing (SILPA) in the Financial Management and Assets Board of the District of Musi Banyuasin in period of 2016 to 2018.. This study uses a qualitative method. Data collection techniques are carried out through field studies by conducting documentation and interviews, literature studies from literature references that support this research. Data analysis techniques start from qualitative data in the form of Reports on the Realization of Regional Income and Expenditure Budgets and Reports on Changes in Budget Balances. The Results of study indicate that the high and low levels of SiLPA that occurred in BPKAD in the District of Musi Banyuasin in the period 2016 to 2018 caused by exceeding income, remaining expenses or other consequences. While SILPA is caused by an increase in regional income, the absorption of the regional budget that is not optimal, the low absorption of unexpected expenditure, the high level of financing receipts but the low cost of financing which means that there are funds that are not utilized optimally, the quantity of human resources in lacking so that the planned target achievement is not optimal.
\end{abstract}

Keywords : The Budget, revenue, expenditure, SiLPA

\section{PENDAHULUAN}

Anggaran Pendapatan dan Belanja Daerah (APBD) merupakan instrumen kebijakan pemerintah daerah yang disusun berdasarkan ketentuan perundang-undangan yang berlaku. Selain itu APBD juga menjadi sarana bagi pihak tertentu untuk melihat dan mengetahui kemampuan daerah baik dari sisi pendapatan dan sisi belanja. Pada sisi pendapatan daerah perkembangan APBD dapat menjadi dasar perencanaan jangka pendek dengan asumsi bahwa perkembangan yang terjadi satu periode mendatang relatif sama. Selisih antara anggaran pendapatan daerah dengan anggaran belanja daerah mengakibatkan terjadinya surplus atau defisit APBD. Surplus anggaran terjadi apabila anggaran 
pendapatan lebih besar dari anggaran belanja. Defisit anggaran terjadi apabila anggaran pendapatan lebih kecil dari anggaran belanja.

Dalam Undang-Undang Republik Indonesia Nomor 33 Tahun 2004 tentang Perimbangan Keuangan Antara Pemerintah Pusat dan Pemerintah Daerah, Pasal 84 menyebutkan dalam hal APBD diperkirakan defisit, maka ditetapkan pembiayaan untuk menutup defisit tersebut yang diantaranya dapat bersumber dari sisa lebih perhitungan anggaran (SiLPA) tahun sebelumnya. Dalam Permendagri Nomor 13 Tahun 2006 tantang Pedoman Pengelolaan Keuangan Daerah, Pasal 137 menyebutkan bahwa sisa lebih perhitungan anggaran tahun sebelumnya merupakan penerimaan pembiayaan yang digunakan untuk menutupi defisit anggaran, apabila realisasi pendapatan lebih kecil daripada realisasi belanja.

Dalam penyusunan APBD angka Sisa Lebih Pembiayaan Anggaran (SILPA) seharusnya sama dengan nol artinya bahwa penerimaan pembiayaan harus dapat menutupi defisit anggaran yang terjadi. Jika angka Sisa Lebih Pembiayaan Anggaran (SILPA) dalam keadaan positif berarti ada pembiayaan netto setelah dikurangi dengan defisit anggaran masih tersisa yang artinya secara anggaran masih ada dana penerimaan pembiayaan yang belum dimanfaatkan untuk membiayai belanja daerah dan/atau pengeluaran pembiayaan daerah. Jika angka Sisa Lebih Pembiayaan Anggaran (SILPA) dalam keadaan negatif berarti pembiayaan netto belum dapat menutupi defisit anggaran yang terjadi, untuk itu perlu dicari jalan keluar misal dari sumber pembiayaan yang lain seperti utang, mengurangi belanja atau pengeluaran pembiayaan sehingga angka SILPA sama dengan nol.

Tingginya angka surplus dan juga defisit dalam suatu anggaran mempengaruhi kinerja pemerintah. Anggaran merupakan alat yang efektif sebagai pengendalian dan penilaian kinerja pemerintah. Pemerintah mengoreksi kinerjanya melalui hasil akhir anggaran yang diperoleh pada akhir tahun. Untuk sebuah anggaran yang baik, SiLPA dan SiKPA menjadi dua hal yang sangat dihindari karena walaupun adanya SiLPA dalam satu tahun anggaran memberikan gambaran ketidakcermatan dalam penganggaran dan lemahnya efektifitas realisasi anggaran dalam pelaksanaan APBD serta rendahnya penyerapan belanja modal. 
Begitu pula jika terjadi SiKPA diartikan bahwa pemerintah kurang cermat dalam menggunakan anggaran yang ada sebab tidak bisa menyesuaikan dengan yang telah ditargetkan atau terdapat ketidaksempurnaan dalam perencanaan kegiatan sehingga mengakibatkan adanya dana-dana yang tidak terealisasikan.

Berikut ini gambaran Laporan Realisasi Anggaran Pendapatan dan Belanja Daerah Pemerintah Kabupaten Musi Banyuasin : 
Tabel 1

Laporan Realisasi Anggaran Pendapatan dan Belanja Daerah Pemerintah Kabupaten Musi Banyuasin

Tahun Anggaran 2016 - 2018

(dalam jutaan rupiah)

\begin{tabular}{|c|c|c|c|c|c|c|c|c|c|}
\hline \multirow{2}{*}{ Uraian } & \multicolumn{3}{|c|}{ Tahun 2016} & \multicolumn{3}{|c|}{ Tahun 2017} & \multicolumn{3}{|c|}{ Tahun 2018} \\
\hline & Anggaran & Realisasi & $\%$ & Anggaran & Realisasi & $\%$ & Anggaran & Realisasi & $\%$ \\
\hline PENDAPATAN - LRA & $2.849 .225,68$ & $2.640 .255,19$ & 92,67 & $2.876 .720,00$ & $2.642 .776,00$ & 91,87 & $2.979 .978,61$ & $3.019 .699,83$ & 101,33 \\
\hline BELANJA & $2.516 .296,93$ & $2.280 .009,35$ & 90,61 & $2.566 .618,02$ & $2.340 .644,99$ & 91,20 & $3.082 .227,68$ & $2.569 .468,00$ & 83,36 \\
\hline TANSFER & $347.139,83$ & $345.117,73$ & 99,42 & $310.454,54$ & $278.835,03$ & 89,82 & $397.850,93$ & $388.592,29$ & 97,67 \\
\hline $\begin{array}{l}\text { SURPLUS/(DEFISIT) } \\
\end{array}$ & $(14.211,08)$ & $15.128,12$ & $(\mathbf{1 0 6 , 4 5 )}$ & $(352,55)$ & $23.295,98$ & & $(500.100,00)$ & $61.639,53$ & $(12,33)$ \\
\hline \multicolumn{10}{|l|}{ PEMBIAYAAN } \\
\hline $\begin{array}{l}\text { PENERIMAAN } \\
\text { PEMBIAYAAN }\end{array}$ & $30.386,08$ & $30.399,43$ & 100,04 & $29.352,55$ & $29.823,28$ & 101,60 & $525.000,00$ & $221.311,63$ & 42,15 \\
\hline Penggunaan SiLPA & $30.384,83$ & $30.397,43$ & 100,04 & $29.352,55$ & $29.823,28$ & 101,60 & $75.000,00$ & $24.126,96$ & 32,17 \\
\hline Pinjaman Dalam Negeri & 0,00 & 0,00 & 0,00 & 0,00 & 0,00 & 0,00 & $450.000,00$ & $197.184,67$ & 43,82 \\
\hline Penerimaan Piutang & 0,00 & 0,00 & 0,00 & 0,00 & 0,00 & 0,00 & 0,00 & 0,00 & 0,00 \\
\hline $\begin{array}{l}\text { Penerimaan Kembali } \\
\text { Investasi }\end{array}$ & 1,25 & 2,00 & 159,87 & 0,00 & 0,00 & 0,00 & 0,00 & 0,00 & 0,00 \\
\hline $\begin{array}{l}\text { PENGELUARAN } \\
\text { PEMBIAYAAN }\end{array}$ & $16.175,00$ & $16.175,00$ & 100,00 & $29.000,00$ & $29.000,00$ & 100,00 & $24.900,00$ & $35.461,70$ & 142,42 \\
\hline $\begin{array}{l}\text { Penyertaan } \\
\text { Modal/Investasi } \\
\text { Pemerintah Daerah }\end{array}$ & $16.175,00$ & $16.175,00$ & 100,00 & $29.000,00$ & $29.000,00$ & 100,00 & $24.900,00$ & $24.900,00$ & 100,00 \\
\hline $\begin{array}{l}\text { Pembayaran Pokok } \\
\text { Pinjaman Dalam Negeri }\end{array}$ & 0,00 & 0,00 & 0,00 & 0,00 & 0,00 & 0,00 & 0,00 & $10.561,70$ & \\
\hline PEMBIAYAAN NETTO & $14.211,08$ & $14.224,43$ & 100,09 & 352,55 & 823,28 & 233,52 & $500.100,00$ & $185.849,92$ & 37,16 \\
\hline $\begin{array}{r}\text { SISA LEBIH PEMBIAYAAN } \\
\text { ANGGARAN (SILPA) }\end{array}$ & $\mathbf{0 , 0 0}$ & $29.352,55$ & & $\mathbf{0 , 0 0}$ & $24.119,26$ & & $\mathbf{0 , 0 0}$ & $247.489,46$ & \\
\hline
\end{tabular}

Sumber : BPKAD Kabupaten Musi Banyuasin, 2020, data diolah. 
Fenomena yang terjadi pada Realisasi Anggaran Pendapatan dan Belanja Daerah Pemerintah Kabupaten Musi Banyuasin dilihat dari Realisasi Anggaran Tahun 2016 sampai dengan Anggaran Tahun 2018 di atas, terlihat terjadi sisa anggaran (SILPA) setiap tahunnya, padahal anggaran yang ditetapkan sebelumnya (APBD) pemerintah daerah telah menetapkan prediksi akan terjadi defisit dimana pendapatan daerah tidak dapat menutupi belanja daerah. Selain itu SILPA dalam APBD diharuskan bernilai 0 (nol) atau nihil. Berdasarkan asumsi sementara dari data di atas, Penulis menyimpulkan faktor-faktor penyebab terjadinya SiLPA dan SILPA pada realisasi APBD Kabupaten Musi Banyuasin adalah pelampauan pendapatan, sisa belanja, peningkatan pendapatan, penyerapan anggaran belanja yang tidak maksimal.

Berdasarkan fenomena di atas, maka Penulis tertarik melakukan penelitian dengan judul : "Analisis faktor-faktor penyebab SiLPA dan SILPA pada Badan Pengelola Keuangan dan Aset Daerah Kabupaten Musi Banyuasin”.

\section{LANDASAN TEORI}

\subsection{Konsep Anggaran}

Menurut Munandar (2001:3), Anggaran merupakan suatu rencana yang disusun secara sistematis, yang meliputi seluruh kegiatan perusahaan, yang dinyatakan dalam unit (kesatuan) moneter dan berlaku dalam jangka waktu (periode) tertentu yang akan datang. Sedangkan menurut Nafarin (2007:11), Anggaran adalah suatu rencana kuantitatif (satuan jumlah) periodik yang disusun berdasarkan program yang telah disahkan.

Berdasarkan beberapa definisi di atas dapat disimpulkan anggaran adalah rencana kerja atau pernyataan estimasi kinerja keuangan pemerintah meliputi rencana pendapatan, belanja, transfer, dan pembiayaan yang diukur dalam satuan rupiah, yang disepakati, ditetapkan dan disusun menurut klasifikasi tertentu secara sistemasis untuk satu periode tertentu melalui suatu proses yang disebut penganggaran. Anggaran Pendapatan dan Belanja Daerah (APBD) adalah rencana keuangan pemerintah daerah yang disepakati dan ditetapkan bersama oleh kepala daerah dan DPRD dalam bentuk peraturan daerah. 
Kebijakan anggaran adalah suatu instrumen kebijakan yang dilakukan pemerintah dalam rangka mempengaruhi tingkat kegiatan ekonomi melalui pengendalian dan pengeluaran pemerintah. Kebijakan anggaran terdiri dari :

1. Kebijakan anggaran berimbang

Kebijakan anggaran berimbang adalah kebijakan yang menghendaki terjadinya keseibangan antara pendapatan dan pengeluaran.

2. Kebijakan anggaran defisit

Kebijakan anggaran defisit adalah kebijakan yang menghendaki posisi pengeluaran lebih besar dari pada posisi penerimaan.

3. Kebijakan anggaran surplus

Kebijakan anggaran surplus adalah kebijakan yang menghendaki belanja lebih kecil dari pada pendapatan/penerimaan yang tersedia.

4. Kebijakan anggaran dinamis

Kebijakan anggaran dinamis dibedakan menjadi 2 (dua) yaitu dinamis absolut yaitu munculnya peningkatan jumlah pada tabungan pemerintah yang bertujuan untuk menggali sumber daya dalam negeri untuk pembiayaan pembangunan. Dan dinamis relatir yaitu persentase dalam ketergantungan pembiayaan perekonomian nasional terhadap bantuan pada daerah diluar negeri atau utang yang ada diluar negeri semakin kecil.

\subsection{Selisih Anggaran}

Selisih anggaran adalah perbedaan antara anggaran dengan realisasi anggaran yang dapat menyebabkan selisih lebih atau selisih kurang. Sisa anggaran adalah selisih antara realisasi penerimaan dan pengeluaran yang dapat menyebabkan sisa lebih atau sisa kurang. Sisa lebih yaitu dana yang belum terpakai selama satu tahun anggaran atau masih tersisa pada akhir tahun anggaran. Ada dua bentuk sisa lebih anggaran yaitu SiLPA dan SILPA.

Menurut Tanjung (2014:91), SiLPA adalah selisih antara realisasi pendapatan dan belanja, serta penerimaan dan pengeluaran pembiayaan daerah selama satu periode pelaporan. Sedangkan menurut Mursyidi (2013:70), SiLPA 
adalah selisih lebih realisasi penerimaan (pendapatan daerah) dan pengeluaran (belanja daerah) selama satu periode anggaran.

Berdasarkan Peraturan Pemerintah Nomor 71 Tahun 2010 tentang Standar Akuntansi Pemerintah, SiLPA/SiKPA (dengan huruf “i” kecil) adalah Sisa Lebih/Kurang Pembiayaan Anggaran yaitu selisih lebih/kurang antara realisasi pendapatan-LRA dan belanja serta penerimaan dan pengeluaran pembiayaan dalam APBN/APBD selama satu periode pelaporan. Arti SiLPA lainnya sebagaimana diatur dalam Pasal 60 Ayat 1 (satu) huruf a, dan paragraf 1 (satu) Pasal 62, serta paragraf 1 (satu) Pasal 137 Peraturan Menteri Dalam Negeri Nomor 13 Tahun 2006 tentang Pedoman Pengelolaan Keuangan Daerah sebagaimana diubah terakhir dengan Peraturan Menteri Dalam Negeri Nomor 21 Tahun 2011, SiLPA adalah Sisa Lebih Perhitungan Anggaran Tahun Sebelumnya.

Dari kedua ketentuan peraturan tersebut diatas, maka yang diberi arti dan pengertian hanyalah SiLPA sedangkan SILPA tidak diberi arti dan pengertian apapun. Arti SILPA dapat ditemukan dalam Peraturan Menteri Dalam Negeri Nomor 38 Tahun 2018 tentang Pedoman Penyusunan Anggaran Pendapatan dan Belanja Daerah Tahun Anggaran 2019 pada Lampiran III Kebijakan Penyusunan APBD, angka 3 (tiga) Pembiayaan Daerah huruf c, SILPA (dengan huruf “i” besar) adalah Sisa Lebih Pembiayaan Tahun Berjalan. Serta SILPA diberi batasan sebagai selisih antara surplus/defisit anggaran dengan pembiayaan netto.

Yang pasti SiLPA dan SILPA adalah hal yang berhubungan erat dengan masalah pembiayaan. Pembiayaan untuk memanfaatkan surplus disebut dengan pengeluaran pembiayaan sedangkan pembiayaan untuk menutupi defisit anggaran sering disebut sebagai penerimaan pembiayaan.

Berdasarkan Peraturan Menteri Dalam Negeri Nomor 13 Tahun 2006 tentang Pedoman Pengelolaan Keuangan Daerah sebagaimana diubah terakhir dengan Peraturan Menteri Dalam Negeri Nomor 21 Tahun 2011 Pasal 62, komponen pembentuk Sisa Lebih Perhitungan Anggaran Tahun Anggaran Sebelumnya (SiLPA) mencakup pelampauan penerimaan PAD, pelampauan penerimaan dana perimbangan, pelampauan penerimaan lain-lain pendapatan daerah yang sah, pelampauan penerimaan pembiayaan, penghematan belanja, 
kewajiban kepada pihak ketiga sampai akhir tahun belum terselesaikan, dan sisa dana kegiatan lanjutan. Dari komponen SiLPA tersebut, secara garis besar terdapat dua unsur pembentuk SiLPA yaitu pelampauan pendapatan daerah dan sisa belanja daerah.

\subsection{Surplus/Defisit}

Surplus adalah Selisih lebih antara pendapatan dan belanja selama satu periode pelaporan atau suatu kondisi dimana pendapatan lebih besar daripada pengeluaran. Sedangkan Defisit adalah Selisih kurang antara pendapatan dan belanja selama satu periode pelaporan atau suatu kondisi dimana pengeluaran lebih besar dari pada pendapatan.

\subsection{Laporan Keuangan}

Berdasarkan Standar Akuntansi Pemerintah definisi Laporan Keuangan adalah laporan yang disusun untuk menyediakan informasi yang relevan mengenai posisi keuangan dan seluruh transaksi yang dilakukan oleh suatu entitas pelaporan selama satu periode pelaporan. Komponen-komponen laporan keuangan dalam sistem akuntansi pemerintahan terdiri dari (SAP, 2010:8):

1. Laporan Realisasi Anggaran (LRA)

2. Laporan Perubahan Saldo Anggaran Lebih (Laporan Perubahan SAL)

3. Neraca

4. Laporan Operasional (LO)

5. Laporan Arus Kas (LAK)

6. Laporan Perubahan Ekuitas (LPE)

7. Catatan atas Laporan Keuangan (CaLK)

\section{METODOLOGI PENELITIAN}

\subsection{Metodelogi Penelitian}

Penelitian dilakukan pada Badan Pengelola Keuangan dan Aset Daerah Kabupaten Musi Banyuasin yang beralamat di Jalan. Kolonel Wahid Udin Lk. VII, Kelurahan Serasan Jaya, Kecamatan Sekayu. Waktu penelitian ini lebih kurang 3 (tiga) bulan terhitung dari Bulan Juli-September 2020. 
Adapun jenis data yang digunakan Penulis pada penelitian ini adalah data sekunder berupa data yang diperoleh melalui observasi langsung, wawancara, maupun dokumentasi, berupa Laporan Keuangan BPKAD Kabupaten Musi Banyuasin dari Tahun Anggaran 2016 sampai dengan 2018.

\subsection{Teknik Analisis Data}

Penelitian ini menggunakan teknik analisis deskriptif kualitatif yaitu dengan cara mendeskripsikan penerapan Standar Akuntansi Pemerintahan Berbasis Akrual pada Laporan Keuangan BPKADTahun 2016 sampai dengan 2018 dengan melihat dan membandingkan indikator laporan keuangan diantaranya tepat waktu, relevan, andal, dapat dibandingkan, dapat dipahami, meliputi fungsi yang terkait, dokumen dan catatan akuntansi yang digunakan serta prosedur dan ketentuan dalam penerapan SAP berbasis akrual tersebut, sehingga memperoleh gambaran secara umum dan menyeluruh tentang keadaan yang sebenarnya.

\section{HASIL DAN PEMBAHASAN}

\subsection{Analisis Sisa Lebih Perhitungan Anggaran (SiLPA) dan Sisa Lebih Pembiayaan Anggaran (SILPA)}

Penganggaran Sisa Lebih Perhitungan Anggaran Tahun Sebelumnya (SiLPA) harus didasarkan pada perhitungan yang cermat dan rasional dengan mempertimbangkan perkiraan realisasi anggaran tahun sebelumnya dalam rangka menghindari kemungkinan adanya pengeluaran pada tahun anggaran berjalan yang tidak dapat didanai akibat tidak tercapainya SiLPA yang direncanakan.

Berdasarkan Peraturan Menteri Dalam Negeri Nomor 13 Tahun 2006 sebagaimana telah beberapa kali diubah, terakhir dengan Peraturan Menteri Dalam Negeri Nomor 21 Tahun 2011 Pasal 62 bahwa komponen pembentuk SiLPA tersebut, secara garis besar terdapat dua unsur pembentuk SiLPA yaitu pelampauan pendapatan daerah dan sisa belanja daerah. Pelampauan pendapatan dan sisa belanja daerah yang terjadi pada Pemerintah Kabupaten Musi Banyuasin dapat dilihat pada tabel berikut : 
Tabel 2

Pelampauan Pendapatan Daerah

Tahun Anggaran 2016 - 2018

(dalam jutaan rupiah)

\begin{tabular}{|c|c|c|c|}
\hline Tahun & Anggaran & Realisasi & $\begin{array}{c}\text { Pelampauan } \\
\text { Pendapatan }\end{array}$ \\
\hline $\mathbf{1}$ & $\mathbf{2}$ & $\mathbf{3}$ & $\mathbf{4 = 2 - 3}$ \\
\hline 2016 & $2.849 .225,68$ & $2.640 .255,19$ & $(208.970,49)$ \\
\hline 2017 & $2.876 .720,00$ & $2.642 .776,01$ & $(233.943,99)$ \\
\hline 2018 & $2.979 .978,60$ & $3.019 .699,83$ & $39.721,23$ \\
\hline
\end{tabular}

Dari Tabel 2 di atas dapat dilihat pelampauan pendapatan daerah hanya terjadi pada Tahun 2018. Sedangkan Tahun 2016 dan Tahun 2017 realisasi pendapatan lebih rendah dari anggaran pendapatan. Kondisi ini menyebabkan SiLPA Tahun 2018 meningkat, seperti yang terlihat pada Tabel 2.

Tabel 3

Sisa Belanja Daerah

Tahun Anggaran 2016 - 2018

(dalam jutaan rupiah)

\begin{tabular}{|c|c|c|c|}
\hline Tahun & Anggaran & Realisasi & Sisa Belanja \\
\hline $\mathbf{1}$ & $\mathbf{2}$ & $\mathbf{3}$ & $\mathbf{4 = 2 - 3}$ \\
\hline 2016 & $2.516 .296,93$ & $2.280 .009,35$ & $236.287,58$ \\
\hline 2017 & $2.566 .618,02$ & $2.340 .644,99$ & $225.973,03$ \\
\hline 2018 & $3.082 .227,68$ & $2.569 .468,00$ & $512.759,68$ \\
\hline
\end{tabular}

Sumber : BPKAD Kabupaten Musi Banyuasin, 2020, data diolah.

Dari Tabel 3 di atas dapat dilihat Tahun 2016 sampai Tahun 2018 realisasi anggaran belanja lebih rendah dari anggaran belanja, kondisi ini menggambarkan terjadinya penghematan belanja atau sisa belanja yang akan menyebabkan semakin tingginya nilai SiLPA, seperti yang terlihat pada Tabel 3. 
Tabel 4

Perkembangan SiLPA

Tahun Anggaran 2016 - 2018

\begin{tabular}{|c|c|c|c|}
\hline Tahun & $\begin{array}{c}\text { Pelampauan } \\
\text { Pendapatan }\end{array}$ & Sisa Belanja & SiLPA \\
\hline $\mathbf{1}$ & $\mathbf{2}$ & $\mathbf{3}$ & $\mathbf{4 = 2 + 3}$ \\
\hline 2016 & $(208.970,49)$ & $236.287,58$ & $27.317,09$ \\
\hline 2017 & $(233.943,99)$ & $225.973,03$ & $7.970,96$ \\
\hline 2018 & $39.721,23$ & $512.759,68$ & 552.480 .91 \\
\hline
\end{tabular}

Kedua unsur diatas merupakan faktor pembentuk SiLPA tahun sebelumnya yang berasal dari selisih lebih antara realisasi penerimaan dan realisasi pengeluaran anggaran selama satu periode anggaran dan harus digunakan dalam tahun berjalan. Karena anggaran disahkan sebelum tahun berjalan maka nilai SiLPA yang ada pada anggaran tahun berjalan merupakan nilai estimasi. Pada tabel 3 dapat dilihat tinggi rendahnya SiLPA di pengaruhi pelampauan pendapatan dan penghematan belanja. Selain dua unsur tersebut terdapat faktor-faktor lain yang mempengaruhi SiLPA yang tidak diteliti pada penelitian ini.

Berdasarkan analisis dan pembahasan yang telah dilakukan di atas faktor -faktor pembentuk SILPA adalah surplus/(defisit) dan pembiayaan netto, maka dapat di gambarkan terdapat korelasi antara surplus/(defisit) dan pembiayaan netto terhadap pembentukan SILPA, yang dapat digambarkan dengan rumus sebagai berikut :

SURPLUS/(DEFISIT) + PEMBIAYAAN NETTO = SILPA POSITIF/(SILPA NEGATIF)

SILPA yang merupakan Sisa Lebih Pembiayaan Anggaran Tahun Berkenaan yaitu penjumlahan antara surplus dengan pembiayaan netto disajikan secara akumulasi dalam Laporan Perubahan Saldo Anggaran Lebih (SAL) yang menyajikan informasi kenaikan/penurunan SAL tahun pelaporan dibandingkan 
dengan tahun sebelumnya. Berikut gambaran pertumbuhan Perubahan Saldo Anggaran Lebih Kabupaten Musi Banyuasin Tahun 2016 - 2018

Tabel 5

Laporan Perubahan Saldo Anggaran Lebih

Kabupaten Musi Banyuasin

Tahun Anggaran 2016-2018

(dalam jutaan rupiah)

\begin{tabular}{|c|c|c|c|c|}
\hline \multirow[b]{2}{*}{ NO } & \multirow{2}{*}{ URAIAN } & \multicolumn{3}{|c|}{ TAHUN } \\
\hline & & 2016 & 2017 & 2018 \\
\hline 1 & SALDO ANGGARAN LEBIH AWAL & $30.397,43$ & $29.352,55$ & $24.119,26$ \\
\hline 2 & $\begin{array}{l}\text { PENGGUNAAN SALDO } \\
\text { ANGGARAN LEBIH }\end{array}$ & $30.397,43$ & $29.823,28$ & $24.126,96$ \\
\hline 3 & SUBTOTAL (1-2) & $(\mathbf{0 , 0 0})$ & $(470,73)$ & $(7,70)$ \\
\hline 4 & $\begin{array}{l}\text { SISA LEBIH/KURANG } \\
\text { PEMBIAYAAN ANGGARAN } \\
\text { TAHUN BERJALAN }\end{array}$ & $29.352,55$ & $24.119,26$ & $247.489,46$ \\
\hline 5 & SUBTOTAL (3+4) & 29.352,55 & 23.648,53 & $247.481,76$ \\
\hline 6 & $\begin{array}{l}\text { KOREKSI KESALAHAN } \\
\text { PEMBUKUAN TAHUN } \\
\text { SEBELUMNYA }\end{array}$ & 0,00 & 470,73 & 7,700 \\
\hline 7 & LAIN-LAIN & 0,00 & 0,00 & 0,00 \\
\hline 8 & $\begin{array}{l}\text { SALDO ANGGARAN LEBIH } \\
\text { AKHIR }(5+6+7)\end{array}$ & 29.352,55 & $24.119,26$ & 247.489,46 \\
\hline
\end{tabular}

Sumber : BPKAD Kabupaten Musi Banyuasin, 2020, data diolah

Dari Tabel 5. tergambar bahwa Saldo Anggaran Awal Tahun 2016 sebesar Rp. 30.397, 43 juta yang merupakan Saldo Anggaran Lebih akhir Tahun 2015, Saldo Anggaran Lebih akhir Tahun 2016 sebesar Rp. 29.352,55 juta, Tahun 2017 sebesar Rp. 24.119,26 juta dan Tahun 2018 sebesar Rp. 247.489,46 juta. Saldo Anggaran Lebih Akhir tersebut akan menjadi sumber penerimaan pembiayaan sebagai akun Penggunaan SiLPA. Berdasarkan data yang telah disajikan pemerintahan kabupaten Musi Banyuasin setiap tahunnya SILPA selalu dianggarkan bernilai 0 (nol) atau nihil (tanpa nilai rupiah) namun nilai realisasinya jauh lebih besar bahkan cenderung terjadi peningkatan, kondisi tersebut seharusnya dihindari atau diminimalisir.

Sudah dijelaskan sebelumnya bahwa SiLPA/SiKPA dan SILPA/SIKPA menjadi 2 (dua) hal yang sangat dihindari karena walaupun adanya SiLPA dalam 1 (satu) tahun anggaran memberikan gambaran ketidakcermatan dalam 
penganggaran dan lemahnya efektifitas realisasi anggaran dalam pelaksanaan APBD serta rendahnya penyerapan belanja modal. Begitu pula jika terjadi SiKPA diartikan bahwa pemerintah kurang cermat dalam menggunakan anggaran yang ada sebab tidak dapat menyesuaikan dengan yang telah ditargetkan atau terdapat ketidaksempurnaan dalam perencanaan kegiatan sehingga mengakibatkan adanya dana-dana yang tidak terealisasikan. Dengan melihat gambar grafik di atas, maka perkembangan SILPA dari Tahun 2015 - 2017 mengalami penurunan namun di Tahun 2018 cenderung mengalami peningkatan yang sangat signifikan.

Berdasarkan analisis dari data yang ada peningkatan SILPA yang terjadi pada Tahun 2018 di sebabkan karena peningkatan nilai surplus dan peningkatan nilai pembiayaan netto. Peningkatan nilai surplus dikarenakan adanya peningkatan pendapatan yang bersumber dari pajak daerah, dana desa dan dana insentif daerah, penyerapan dana belanja daerah yang tidak maksimal terutama pada belanja tidak terduga. Peningkatan nilai pembiayaan netto dikarenakan adanya peningkatan penerimaan pembiayaan yang bersumber dari pinjaman dalam negeri namun pengeluaran pembiayaan terealisasi sangat rendah.

\subsection{Implementasi Hasil Penelitian}

Dari hasil pembahasan yang telah dilakukan di atas dapat digambarkan bahwa APBD merupakan indikator keberhasilan suatu daerah dalam pelaksanaan program pembangunannya. Komponen yang dianggarkan dalam APBD adalah Pendapatan, Belanja dan Pembiayaan. Dari data yang didapat dalam kurun waktu Tahun 2016 - 2018, Pendapatan Asli Daerah (PAD) yang telah dicapai Pemerintah Kabupaten Musi Banyuasin telah mengalami peningkatan setiap tahunnya. Hal ini menggambarkan kinerja pendapatan Pemerintah Daerah Kabupaten Musi Banyuasin sudah baik. Namun dari data di atas dapat dilihat bahwa pendapatan Pemerintah Daerah Kabupaten Musi Banyuasin $85 \%$ berasal dari pendapatan transfer pemerintah pusat. Kondisi ini menunjukkan bahwa PAD belum mampu mendanai secara mandiri penyelenggaraan pelaksanaan program dan kegiatan pemerintahan. Hal ini menjadi salah satu alasan Pemerintah Daerah Kabupaten Musi Banyuasin menerapkan anggaran defisit. Penerapan anggaran defisit disebabkan karena Kabupaten Musi Banyuasin merupakan daerah yang 
pertumbuhan perekonomiaannya belum stabil sehingga Pendapatan Asli Daerah masih rendah dan masih memerlukan bantuan dari pemerintahan pusat dan untuk mengakomodir dana SILPA tahun sebelumnya yang merupakan salah satu komponen penerimaan pembiayaan.

Pada Komponen Belanja dari data yang didapat dalam kurun waktu Tahun 2016 - 2018 juga mengalami peningkatan setiap tahunnya. Hal ini menunjukkan bahwa kinerja belanja daerah pada Pemerintah daerah Kabupaten Musi Banyuasin sudah baik karena telah memanfaatkan seoptimal mungkin dana yang ada untuk meningkatkan pelayanan dan kesejahteraan masyarakat. Selisih anggaran yang terjadi pada komponen belanja daerah disebabkan anggaran belanja tidak terserap secara maksimal.

Selisih antara anggaran dan realisasinya yang terjadi pada komponen pendapatan, belanja, dan pembiayaan sangat ditentukan kemampuan Pemerintah Daerah dalam mengestimasi target pendapatan, belanja dan pembiayaan dalam perencanaan. Untuk meminimalisir terjadinya selisih anggaran dan realisasinya dapat dilakukan melalui sistem informasi yang terintegrasi antara perencanaan, penganggaran dan melakukan evaluasi yang lebih mendalam terhadap hambatan-hambatan yang dihadapi sehingga dapat diambil solusi yang tepat dalam penyelesaiannya sehingga tidak terjadi kembali di tahun yang akan datang.

Sisa Lebih Pembiayaan Anggaran (SILPA) adalah penjumlahan antara surplus/(defisit) dengan pembiayaan netto yang merupakan SILPA tahun berkenaan dan menjadi sumber penerimaan pembiayaan untuk tahun berikutnya sebagai akun SiLPA. Terdapat korelasi antara surplus/(defisit), pembiayaan netto dan SILPA. Dapat disimpulkan bahwa faktor-faktor penyebab terjadinya peningkatan surplus/(defisit) dan pembiayaan netto juga merupakan faktor-faktor penyebab terjadinya peningkatan SILPA. Semakin tinggi nilai surplus dan pembiayaan netto, maka semakin tinggi pula nilai SILPA. Oleh karena itu, untuk meminimalisir terjadinya SILPA dapat dilakukan dengan pengendalian nilai surplus/(defisit) dan pembiayaan netto.

Dapat disimpulkan bahwa faktor-faktor yang menyebabkan terjadinya SiLPA (Sisa Lebih Perhitungan Anggaran ) adalah pelampauan pendapatan, 
penghematan belanja dan faktor lain yang tidak diteliti di penelitian ini. Sedangan SILPA (Sisa Lebih Pembiayaan Anggaran) dipengaruhi oleh peningkatan pendapatan daerah, penyerapan anggaran belanja daerah yang tidak maksimal, rendahnya penyerapan belanja tidak terduga, penerimaan pembiayaan yang tidak digunakan secara optimal dan kurangnya Sumber Daya Manusia sebagai pengelola keuangan daerah.

\section{SIMPULAN}

Berdasarkan hasil penelitian dan pembahasan yang dikemukakan sebelumnya, SiLPA dan SILPA merupakan bentuk sisa anggaran yang serupa tapi berbeda. SiLPA dan SILPA telah diberi arti/pemgertian/batasan sebagaimana diatur dengan ketentuan peraturan perundang-undangan yang telah dibahas sebelumnya. Maka dapat diambil simpulan bahwa tinggi rendahnya SiLPA yang terjadi di BPKAD Kabupaten Musi Banyuasin dalam kurun waktu Tahun 2016 2018 disebabkan oleh faktor-faktor sebagai berikut :

1. Pelampauan realisasi pendapatan.

2. Penghematan belanja dan akibat lainnya yang tidak diteliti pada penelitian ini.

Sedangkan SILPA yang terjadi di BPKAD Kabupaten Musi Banyuasin dalam kurun waktu Tahun 2016 - 2018 disebabkan oleh faktor-faktor sebagai berikut :

1. Peningkatan pendapatan daerah yang bersumber Pendapatan Asli Daerah, Pendapatan Transfer dan Lain-lain Pendapatan yang Sah.

2. Penyerapan anggaran belanja daerah yang tidak maksimal karena adanya kegiatan yang tidak terlaksana atau belum selesai terlaksana.

3. Rendahnya penyerapan Belanja Tidak Terduga

4. Tingginya Penerimaan Pembiayaan namun rendahnya Pengeluaran Pembiayaan, yang artinya terdapat dana yang tidak dimanfaatkan secara maksimal.

5. Kuantitas Sumber Daya Manusia yang kurang sehingga pencapaian target yang direncanakan tidak maksimal. 


\section{DAFTAR PUSTAKA}

Ajul. 2011. Definisi Akuntan Sektor Publik. http:// ajul-Akuntansi publik. blogspot. co. id / 2011 / 07 / definisi - akuntansi - publik. html. Diakses tanggal 22 Maret 2019 pukul 10.00 WIB.

Anshar. 2011. Jenis-jenis Anggaran Pemerintah. https:// sibukkerjatugas. wordpress. Com / 2011 / 12 / 16 / jenis - jenis - anggaran - pemerintah /.Diakses tanggal 15 Februari 2019 pukul 14.15 WIB.

Arif,

Bahtiar.

Muchlis.

Iskandar. 2002. Akuntansi

Pemerintahan. Jakarta: Salemba Empat.

Baswir, Revrisond. 2000. Akuntansi Pemerintahan Indonesia. Yogyakarta: BPFE.

Halim , Abdul. 2002. Akuntansi Sektor Publik. Jakarta : Salemba Empat.

Izudin. Syaparudin. Syamsuddin HM. 2018. Kinerja Keuangan Daerah dan Hubungan dengan SilPA di Kabupaten Bungo. https://online-journal.unja.ac.id/index.php/JES/article/view/1340. Diakses tanggal 14 Januari 2019 pukul 12.38 WIB.

Mardiasmo. 2002. Akuntansi Sektor Publik. Yogyakarta. Andi.

Mursyidi. 2013. Akuntansi Pemerintahan di Indonesia. Bandung. Refika Aditama.

Munandar. 2001. Psikologi Industri dan Organisasi. Depok: Universitas Indonesia (UI Press).

Nafarin. 2007. Penganggaran Perusahaan. Jakarta : Salemba Empat.

Peraturan Pemerintah Republik Indonesia Nomor 71 Tahun 2010 tentang Standar Akuntansi Pemerintah.

Peraturan Menteri Dalam Negeri Republik Indonesia Nomor 13 Tahun 2006 tentang Pedoman Pengelolaan Keuangan Daerah.

Peraturan Menteri Dalam Negeri Republik Indonesia Nomor 64 Tahun 2013 tentang Penerapan Standar Akuntansi Pemerintah Berbasis Akrual Pada Pemerintah Daerah.

Peraturan Menteri Dalam Negeri Republik Indonesia Nomor 38 Tahun 2018 tentang Pedoman Penyusunan APBD Tahun Anggaran 2019.

Peraturan Bupati Musi Banyuasin Nomor 82 Tahun 2016 tentang Susunan Organisasi, Uraian Tugas dan Fungsi Badan Pengelola Keuangan dan Asei Daerah Kabupaten Musi Banyuasin. 
Ratna, Ikhwani. 2015. Faktor-faktor Yang Mempengaruhi Jumlah Sisa Lebih Perhitungan Anggaran (SiLPA) Anggaran Pendapatan Daerah Pada Pemerintah Provinsi Riau. http://ejournal.uinsuska.ac.id/index.php/Kutubhanah/article/view/1476 di akses tanggal 26 Februari 2019 pukul 15.45 WIB.

Sugiyono. 2012. Metode Penelitian Bisnis. Bandung : Alfabeta

Tanjung, Abdul Hafizh. 2009. Penatausahaan dan Akuntansi Keuangan Daerah. Jakarta Salemba Empat.

Yulistio. 2012. Pengertian Administrasi dan Administrasi Negara dan Perbedaan Pemerintah-Pemerintahan. https:// yulistio. wordpress. Com / 2012 / 05 / 25 / pengertian - administrasi - dan - administrasi negara - dan - perbedaan - pemerintahan. Diakses tanggal 05/03/2019 pukul 15.47 WIB. 